Journal of Anatolian Environmental and Animal Sciences

(Anadolu Çevre ve Hayvancılık Bilimleri Dergisi)

DOI: https://doi.org/10.35229/jaes.726961

\title{
Weight - Length Relationships (WLRs) of Anchovy, Engraulis encrasicolus with the Evaluation of Overfishing Effects on the Slope (b) in the Black Sea (Turkey)
}

\author{
Sabri BILGIN ${ }^{1 *} \quad$ Ebru SOLAK ${ }^{2}$ \\ ${ }^{1}$ Sinop University Faculty of Fisheries and Aquaculture, TR57000, Sinop, Turkey. \\ ${ }^{2}$ Recep Tayip Erdoğan University Faculty of Fisheries and Aquaculture, TR53000, Rize, Turkey.
}

How to cite: YAZAR. \& YAZAR. (2020). Weight - Length Relationships (WLRs) of Anchovy, Engraulis encrasicolus with the Evaluation of Overfishing Effects on the Slope (b) in the Black Sea (Turkey). J. Anatolian Env. and Anim. Sciences, 5(2), 253-259.

Atıf yapmak için: YAZAR. \& YAZAR. (2020). Karadeniz'de (Türkiye) Hamsi Balığı'nın, Engraulis encrasicolus (Linnaeus, 1758) (Clupeiformes: Engraulidae) Ağırlık-Boy (WLRs) İlişkisi ile Av Baskısının Eğim Parametresi (b) Üzerine Etkisinin Değerlendirilmesi. Anadolu Çev. ve Hay. Dergisi, 5(2), 253-259.

: https://orcid.org/0000-0003-0155-8981 D: https://orcid.org/0000-0002-8701-8099
Abstract: The present study was conducted to determine the weight-length relationships (WLRs) of Anchovy (Engraulis encrasicolus) caught by purse seine off the Rize and Trabzon provinces coasts of the southeastern Black Sea, Turkey and to compare as a whole the WLRs parameters of E. encrasicolus obtained from different fishing seasons and locality for contributing fisheries management of this Black Sea' key fish species. The WLRs parameters showed that $E$. encrasicolus exhibited negative allometric growth characteristics for both sexes (Pauly't test, $P$ $<0.05)$. To compare the estimations calculated from the present study with other studies, $\log (a)$ values were plotted against values of slope $(b)$, proved to be consistent with previous studies data. In addition to this, when the WLRs parameters $(b)$ of Anchovy is evaluated historically, it has been determined that the Anchovy exhibited positive allometric growth in the mid-1985, isometric growth from 1990 to 2000 and negative allometric growth after the 2000s. The overexploitation on anchovy stocks has shown itself in fish growth over the years. This study provides new basic information on the WLRs for Anchovy stocks, in support of sustainable fisheries management of this species and especially of the coastal waters in the Black Sea, Turkey.

Keywords: Anchovy, Black Sea, Engraulis encrasicolus, fisheries management, weight-length relationships (WLRs).
Sabri BILGIN

Sinop University Faculty of Fisheries and Aquaculture, TR57000, Sinop, Turkey. 凶: sbrbilgin@hotmail.com

Telephone $\quad:+90(368) 2876254(3391$

Fax : $90(368) 2876269$

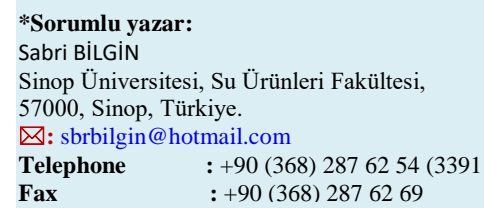

\section{8) (Clupeiformes: Engraulidae) Ağırtk-Boy (V Parametresi (b) Üzerine Etkisinin Değerlendirilmesi}

Öz: $\mathrm{Bu}$ çalışma, hamsi (Engraulis encrasicolus) balığının boy ağırlık ilişkisi (WLRs) parametrelerini belirlemek için güney doğu Karadeniz'de Rize ve Trabzon illeri civarında gırgır ağları ile örneklenen bireyler üzerinden yürütülmüş olup ayrıca bu anahtar balık türünün Karadeniz'deki balıkçılık yönetimine katkı sağlamak amacıyla daha önce farklı av sezonlarında yürütülmüş çalışmalardan elde edilen WLRs parametreleri bir bütünlük içerisinde karşılaştırılmıştır. WLRs parametreleri dişi ve erkek bireylerin negatif allometrik büyüme (Pauly t-test, $P<0,05)$ özelliği gösterdiğini ortaya koymuştur. Ayrıca, önceki çalışmalardan elde edilen $\log (a)$ ve $b$ değerleri regresyona tabi tutulduğunda, bu çalışmada elde edilen sonuçların önceki çalışmalarla tutarlı olduğu belirlenmiştir. WLRs denklemi parametresi $(b)$ tarihsel olarak değerlendirildiğinde, Hamsi balığının 1985 ortalarında pozitif allometrik büyüme, 1990-2000 arasında izometrik büyüme ve 2000 'lerden sonra ise negatif allometrik büyüme sergilediği tespit edilmiştir. Hamsi stoklarındaki aşırı sömürü, yıllar boyunca balık büyümesinde kendini göstermiştir. Bu çalışma, Türkiye'nin Karadeniz kıyı sularında Hamsi stoklarının sürdürülebilir balıkçılık yönetimini desteklemek için türün boy ağırlık ilişkisi hakkında yeni temel bilgiler sunmaktadır.

Anahtar kelimeler: Ağırlık-boy ilișkisi (WLRs), balıkçılık yönetimi, Engraulis encrasicolus, Hamsi, Karadeniz. 


\section{INTRODUCTION}

Anchovy, Engraulis encrasicolus (Linnaeus, 1758), is distributed Eastern Atlantic: Bergen, Norway to East London, South Africa, Mediterranean and Black Sea (Froese \& Pauly, 2019). Anchovy are regularly caught in the Mediterranean and Black Sea on the coasts of Spain, France, Italy, Russia, Ukraine, Bulgaria, Croatia, Romania, Greece, Georgia, and Turkey. Feeds on planktonic organisms such as fish eggs and larvae, Ctenophorans and copepods, etc. (Mazlum et al., 2017). Spawns from April to November with peaks usually in the warmest months (Ribeiro et al., 1996; Froese \& Pauly, 2019). It is one of the most important migratory commercial small pelagic and fast growing fish species in the Black Sea and mainly caught by mid-water trawl (legal Anchovy fisheries with mid-water trawl towed behind two boats are conducted only in Samsun region in Turkey) and purse seine in the seven and a half months during the fishing season (between 31 August and 15 April) along the coast of Turkey. Anchovy tends to move further north and into surface waters in summer, retreating and descending in winter and during a fishing season average annual catch constitute about $69 \%$ of the total marine fisheries production of Turkey (Bilgin et al., 2013). In the Black Sea, the spawning season of Anchovy lasts from mid May, when water temperature is about $15-16^{\circ} \mathrm{C}$, to the middle or end of August when the temperature is about 25 $26^{\circ} \mathrm{C}$ (Lisovenko \& Andrianov, 2006). Within the spawning season one average female can produce about 50 batches of more than 200,000 eggs (Lisovenko \& Andrianov, 2006). The maximum total length of Anchovy was reported as $16.85 \mathrm{~cm}$ in 1986-1987 fishing season by Karacam \& Düzgünes (1990) and also four age groups (0, I, II and III) were reported by different authors in different fishing seasons in the Black Sea (Erkoyuncu \& Özdamar, 1989; Karacam \& Düzgünes, 1990; Ünsal, 1989; Mutlu, 1994; Özdamar et al., 1995; Kayalı, 1998; Mutlu, 2000; Gözler \& Çiloğlu, 1998; Samsun et al., 2004; Samsun et al., 2006; Aka et al., 2004; Bilgin et al., 2006; Şahin et al., 2008; Erdoğan Sağlam \& Sağlam, 2010). All reproductive, growth and also mortality parameters of Black Sea Anchovy are very variable seasonally and annually (Bilgin, 2006; Lisovenko \& Andrianov, 2006; Bilgin et al., 2016).

Knowledge on biological features such as reproduction, growth and weight length relationships (WLRs) are important tools for fisheries management. The information on the WLRs could contribute to the management of natural stocks of fish species which is ecologically and economically important, and possibly has suffered threats from overfishing, pollution and climate change (Oliveria et al., 2012) and also the WLRs allow estimating food and feeding, life histories of certain species (Stergiou \& Moutopoulos, 2001). In addition to these, the WLRs parameters can be affected by different factors such as environmental conditions, gonad maturity stages, sex, stomach fullness, health condition, season, population and differences within species (Froese, 2006; Oliveria et al., 2012). Thus, they are an important component of fisheries biology and when properly calculated they can be very useful to fisheries management (Froese et al., 2011). The weight $(W)$ of fish and other organisms is exponentially related to their length $(L)$ according to the equation $W=\mathrm{a} L^{\mathrm{b}}$, where $a$ is the intercept and $b$ is the slope of the relation (Le Cren, 1951). Based on the slope $(b)$ of the relation between $W$ and $L$, one can check whether the growth of a fish species is isometric $(b=3)$, negative allometric-hypoallometric $(b<$ $3)$ or positive allometric-hyperallometric $(b>3)$.

The Anchovy is the main object of fishing industry in Turkey. So the knowledge of its biological properties including the WLRs parameters is necessary for fisheries management. The WLRs parameters of this Black Sea' key fish species were previously reported from different geographic regions and different fishing seasons in the Black Sea (Erkoyuncu \& Özdamar, 1989; Karacam \& Düzgünes, 1990; Ünsal, 1989; Mutlu, 1994; Özdamar et al., 1995; Kayalı, 1998; Mutlu, 2000; Gözler \& Çiloğlu, 1998; Samsun et al., 2004; Samsun et al., 2006; Aka et al., 2004; Bilgin et al., 2006; Şahin et al., 2008; Erdoğan Sağlam \& Sağlam, 2010). Moreover, previous research into the WLRs parameters of Anchovy has been rather fragmentary in the Black Sea. The present study was conducted to determine the WLRs of Anchovy caught by purse seine during the 20132014 fishing season off the Rize and Trabzon provinces coasts in the southeastern Black Sea, Turkey and also to compare as a whole the WLRs parameters of Anchovy from different geographical locality and fishing seasons in support of sustainable fisheries management.

\section{MATERIAL AND METHOD}

Sample Collection: Samples of the Anchovy (Engraulis encrasicolus) were collected at random from the commercial purse seine at the southern area of the Black Sea (off Rize and Trabzon provinces, Turkey) from September 2013 to April 2014 in 2013-2014 fishing season. After the purse seine fishing operation, a box of Anchovy $(\approx 18 \mathrm{~kg})$ was taken from the catch and brought to the Recep Tayyip Erdoğan University Fisheries Faculty Laboratory for examination.

Weight - Length Relationships (WLRs): The total length $(T L)$ and the wet body weight $(W)$ of E. encrasicolus were measured after blot drying with a piece of clean towel. All specimens were measured to the nearest $0.1 \mathrm{~cm}$ and weighed to the nearest $0.01 \mathrm{~g}$. The weight-length relationships (WLRs) parameters were calculated and analyzed using MS Excel software. However to compare the 
WLRs results for E. encrasicolus obtained in this study with the results of previous studies, the $\log (a)$ values were drawn against $b$ values.

The weight length relationship was estimated as (Le Cren, 1951):

$$
W=\mathrm{a} T L^{\mathrm{b}},
$$

where $W$ is the body weight $(\mathrm{g}), T L$ is the total length $(\mathrm{cm}), a$ is the intercept, and $b$ is the slope of the regression line. Comparison of the difference of slope value from $b=3$ (isometric growth), Pauly's $t$-test was performed (Pauly, 1984). Pauly's $t$-test statistic was calculated as below:

$$
t=\frac{S d_{\log T L}}{S d_{\log W}} \frac{|\mathrm{b}-3|}{\sqrt{1-r^{2}}} \sqrt{n-2}
$$

where $S d_{\log T L}$ is the standard deviation of the $\log T L$ values, $S d_{\log W}$ is the standard deviation of the $\log W$ values, $\mathrm{n}$ is the number of specimens of E. encrasicolus used in the computation. The value of $b$ is different from $b=3$ if calculated $t$ value is greater than the table $t$ values for $\mathrm{n}-2$ degrees of freedom (Pauly, 1984). Comparison of the difference of correlation coefficient $(r)$ from zero $t$-test (Snedecor \& Cochran, 1989) was calculated as follow:

$$
t=\frac{r^{*} \sqrt{(n-2)}}{\sqrt{\left(1-r^{2}\right)}}
$$

where $n$ is the number of fish used in the computation and $r$ is the correlation coefficient. The value of correlation coefficient is different from zero if $t$ value is greater than the tabled $t$ values for $\mathrm{n}-2$ degrees of freedom. $\mathrm{T}$ test was used to compare the means between the sexes in PAST ver. 1.75b software package (Hammer et al., 2001). Differences were considered statistically significant when $P$ $<0.05$.

\section{RESULTS AND DISCUSSION}

Size Structure: A total of 5485 E. encrasicolus (3336 female, 2149 male) were sampled from September 2013 to April 2014 and the maximum total length was measured as $13.8 \mathrm{~cm}$ for females and $13.2 \mathrm{~cm}$ for males. The mean total length of females $(10.8 \pm 0.02 \mathrm{~cm})$ was significantly greater than mean total length of males $(10.1 \pm 0.03 \mathrm{~cm})(t$ - test; $P<0.05)$.

Weight - Length Relationships (WLRs): The WLRs results and statistics of Anchovy showed below and in Fig. 1. Females: $\mathrm{W}=0.0159 \mathrm{TL}^{2.5609}, \mathrm{R}^{2}=0.8093, \mathrm{n}=$ 3336, $\mathrm{Sd}_{\operatorname{logL}}=0.04294, \mathrm{Sd}_{\log \mathrm{W}}=0.12225$, Pauly't test $=$ 203.78, $P<0.001$ ). (95\% conf. limits of $b$ : from 2.5187 to 2.6032). Males: $\mathrm{W}=0.0078 \mathrm{TL}^{2.8757}, \mathrm{R}^{2}=0.8783, \mathrm{n}=2149$, $\mathrm{Sd}_{\log \mathrm{L}}=0.053783, \mathrm{Sd}_{\log \mathrm{W}}=0.165031$, Pauly't test $=5.405$, $P<0.001$ ). (95\% conf. limits of $b$ : from 2.8307 to 2.9209 ).
The WLRs parameters showed that sampled specimens has negative allometric growth characteristics $(b$ $<3)$ both females $(b=2.5609)$ and males $(b=2.8757)$ (Pauly' $t$ test, $P<0.05$ ) in 2014-2015 fishing season. However, in order to comparison of the difference of correlation coefficient $(r)$ from zero $t$-test (Snedecor and Cochran, 1989) was applied and the values of $(r)$ for females $(r=0.8093)$, for males $(r=0.8783)$ and for combined data $(r=0.8517)$ are different from zero $(P<0.05)$, indicated that Anchovy has higher correlation in WLRs equations.

To compare the estimations calculated from the present study with other studies (showed in Table 2), Log (a) values were plotted against values of $b$ (Fig. 2), proved to be consistent with previous studies (from 1985-1986 fishing season up to 2014-2015 fishing seasons) data for $E$. encrasicolus. The results of regression analysis of $\log (a)$ to slope $(b)$ for E. encrasicolus showed below and in Table 1. Females: $\log (a)=-0.9935^{*}(b)+0.7739\left(\mathrm{R}^{2}=0.9900, \mathrm{n}=\right.$ $11, P<0.05)$. Males: $\log (a)=-1.0131 *(b)+0.8289\left(\mathrm{R}^{2}=\right.$ 0.9872, $\mathrm{n}=11, P<0.05)$. Females+Males: $\log (a)=-$ $1.1661 *(b)+1.3103\left(\mathrm{R}^{2}=0.9024, \mathrm{n}=20, P<0.05\right)$
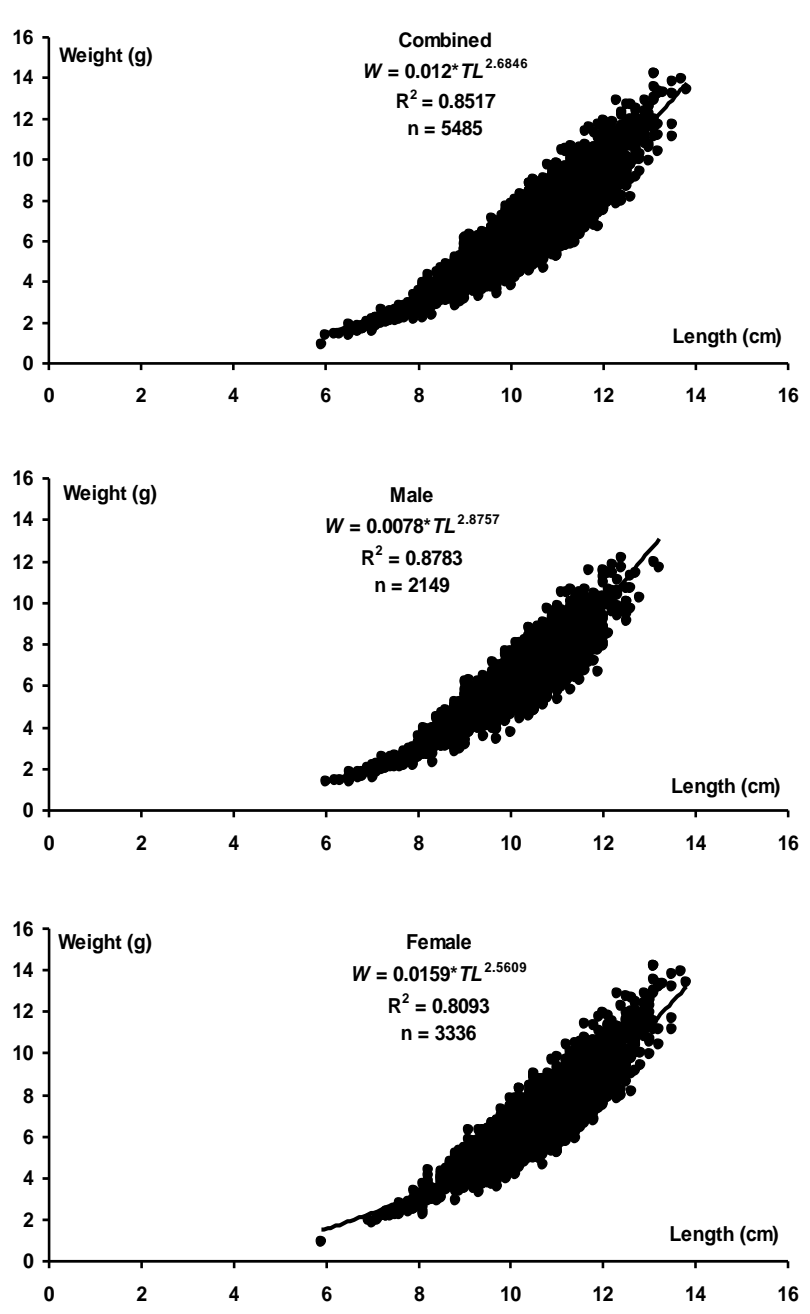

Figure 1. Weight - length relationships (WLRs) of the Anchovy (Engraulis encrasicolus) caught during the 2013-2014 fishing season in the Black Sea. 

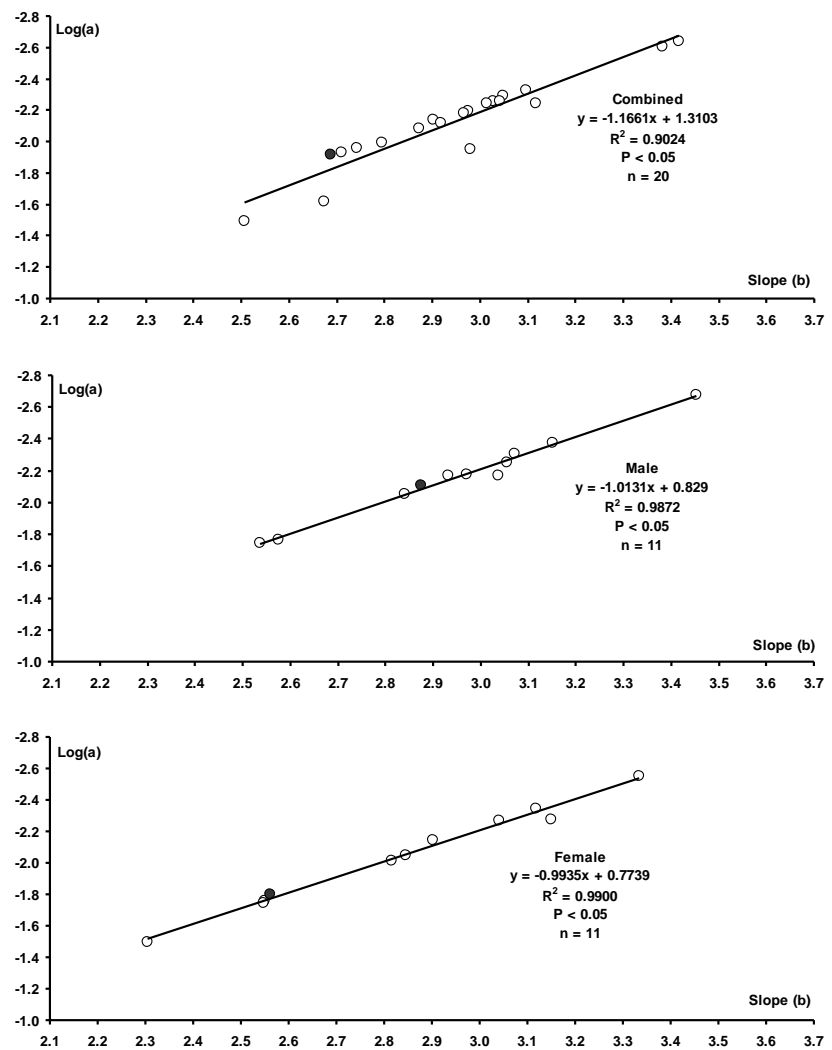

Figure 2. The test plot of $\log (a)$ against $b$ for different WLRs of the Anchovy (Engraulis encrasicolus). Black dot = present study parameter. White dot $=$ estimated parameters of different studies conducted from 1985-1986 to 2013-2014 fishing seasons in the Black Sea (see Table 2).

In terms of fishing season variations, Anchovy exhibited positive allometric growth only in the first two fishing seasons (1985-1986 and 1986-1987). Later, isometric growth up to 1999-2000 fishing seasons and after 2000 years Anchovy has exhibited negative allometric growth and tended to be thinner (Fig. 3).

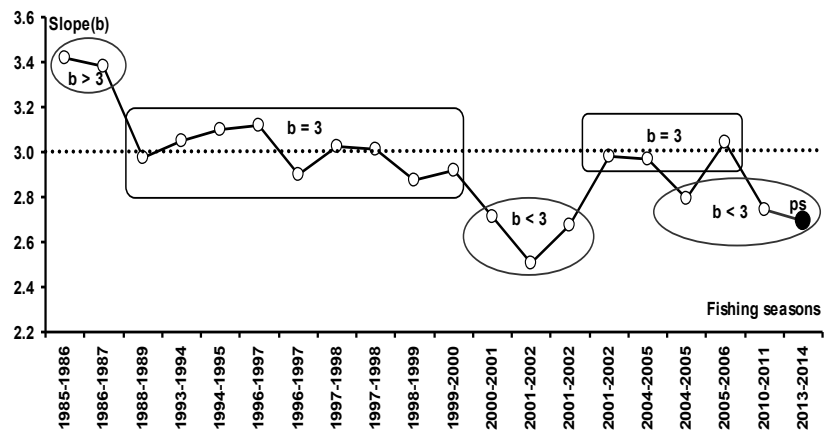

Figure 3. The slope $(b)$ parameter values of the WLRs equation in Anchovy (Engraulis encrasicolus). Black dot (ps) = present study parameter. White dot $=$ estimated parameters of different studies conducted from 1985-1986 to 2013-2014 fishing seasons in the Black Sea.

In all result of the previous studies (a total of 20 fishing seasons results), except for 11 fishing seasons results, conducted between 1985-1986 and 2013-2014 fishing seasons in the Black Sea, the $b$ values were reported regardless of fish sexes (Table 1).

Table 1. Results of regression analysis of $\log (a)$ to slope $(b)$ for the Anchovy (Engraulis encrasicolus). Calculations were done using the data ( $a$ and $b$ ) shown in Table 2. $a$ : Intercept, $b$ (slope): $\mathrm{x}$ - variable 1 .

\begin{tabular}{|c|c|c|c|c|c|c|}
\hline \multirow[b]{2}{*}{ Males+Female. } & \multirow[t]{2}{*}{ Coefficients } & \multirow[t]{2}{*}{$\begin{array}{c}\text { Standard } \\
\text { Error (S.E) } \\
\end{array}$} & \multirow[t]{2}{*}{$T$ - stat } & \multirow[t]{2}{*}{$P$ - values } & \multicolumn{2}{|c|}{$\begin{array}{l}\text { 95\% Confidence Limits } \\
\text { of the Parameters }\end{array}$} \\
\hline & & & & & & \\
\hline Intercept & 1.3103 & 0.2668 & 4.9118 & 0.000112404 & 0.7498 & 1.8707 \\
\hline $\mathrm{x}$ - variable 1 & -1.1661 & 0.0904 & -12.9041 & $1.55379 \mathrm{E}-10$ & -1.3559 & -0.9762 \\
\hline \multicolumn{7}{|c|}{$\log (a)=-1.1661^{*}(b)+1.3103\left(\mathrm{R}^{2}=0.9024, \mathrm{n}=20, P<0.05\right)$} \\
\hline \multicolumn{7}{|c|}{ Males } \\
\hline Intercept & 0.8289 & 0.1141 & 7.2680 & 4.72392E-05 & 0.5709 & 1.0869 \\
\hline $\mathrm{x}$ - variable 1 & -1.0131 & 0.0385 & -26.3338 & $7.93126 \mathrm{E}-10$ & -1.1002 & -0.9261 \\
\hline \multicolumn{7}{|c|}{$\log (a)=-1.0131^{*}(b)+0.8289\left(\mathrm{R}^{2}=0.9872, \mathrm{n}=11, P<0.05\right)$} \\
\hline \multicolumn{7}{|c|}{ Females } \\
\hline Intercept & 0.7739 & 0.0949 & 8.1537 & $1.90063 \mathrm{E}-05$ & 0.5592 & 0.9886 \\
\hline $\mathrm{x}$ - variable 1 & -0.9935 & 0.0333 & -29.8245 & $2.61713 \mathrm{E}-10$ & -1.0689 & -0.9182 \\
\hline \multicolumn{7}{|c|}{$\log (a)=-0.9935^{*}(b)+0.7735\left(\mathrm{R}^{2}=0.9900, \mathrm{n}=11, P<0.05\right)$} \\
\hline
\end{tabular}

Table 2. The weight - length relationships (WLRs) parameters of the Anchovy (Engraulis encrasicolus) from 1985-1986 to 2013-2014 fishing seasons in the Black Sea. $L_{\max }$ : maximum total length $(\mathrm{cm}), a$ : intercept, $b$ : slope. Data $(a$ and $b)$ has been used to draw of test plot of $\log (a)$ against $b$ in Figure 2.

\begin{tabular}{|c|c|c|c|c|c|c|c|c|c|c|c|c|c|c|}
\hline \multirow{3}{*}{$\begin{array}{l}\text { Fishing } \\
\text { seasons }\end{array}$} & \multirow{3}{*}{ Regions } & \multicolumn{12}{|c|}{ Sex } & \multirow{3}{*}{ References } \\
\hline & & \multicolumn{4}{|c|}{ Males } & \multicolumn{4}{|c|}{ Females } & \multicolumn{4}{|c|}{ Males+Females } & \\
\hline & & $L_{\max }$ & $\mathbf{a}$ & b & $\mathbf{r}^{2}$ & $L_{\max }$ & $\mathbf{a}$ & b & $\mathbf{r}$ & $L_{\max }$ & a & b & $\mathbf{r}^{2}$ & \\
\hline 1985-1986 & Sinop-Trabzon & & & & & & & & & 16.1 & 0.0023 & 3.4157 & & 1 \\
\hline 1986-1987 & Trabzon & & 0.0021 & 3.4539 & 0.9978 & & 0.0028 & 3.3331 & 0.9979 & 16.9 & 0.0025 & 3.3832 & 0.9994 & 2 \\
\hline 1988-1989 & Istanbul & 13.0 & & & & 13.0 & & & & 13.0 & 0.0064 & 2.9743 & & 3 \\
\hline 1993-1994 & Trabzon & 14.4 & 0.0068 & 2.9320 & 0.9390 & 13.9 & 0.0072 & 2.9030 & 0.9410 & 14.4 & 0.0051 & 3.0480 & 0.9700 & 4 \\
\hline 1994-1995 & Sinop-Samsun & & & & & & & & & 15.3 & 0.0047 & 3.0975 & 0.9800 & 5 \\
\hline 1996-1997 & Trabzon-Hopa & & 0.0068 & 3.0370 & 0.8600 & & 0.0053 & 3.1490 & 0.9000 & 13.5 & 0.0057 & 3.1170 & 0.8900 & 6 \\
\hline 1996-1997 & Ordu-Hopa & & & & & & & & & 15.7 & 0.0073 & 2.9030 & 0.9690 & 7 \\
\hline 1997-1998 & Ordu-Hopa & & & & & & & & & 15.3 & 0.0055 & 3.0270 & 0.9746 & 7 \\
\hline $1997-1998$ & Rize-Hopa & 13.8 & 0.0049 & 3.0710 & 0.8010 & 13.8 & 0.0054 & 3.0400 & 0.9440 & 13.8 & 0.0057 & 3.0150 & 0.9250 & 8 \\
\hline 1998-1999 & Sinop & & 0.0088 & 2.8404 & & & 0.0317 & 2.3042 & & 14.5 & 0.0083 & 2.8720 & & 9 \\
\hline 1999-2000 & Sinop & & 0.0056 & 3.0549 & & & 0.0097 & 2.8156 & & 14.5 & 0.0076 & 2.9190 & & 9 \\
\hline 2000-2001 & Sinop & 13.8 & 0.0179 & 2.5368 & 0.9000 & 14.1 & 0.0174 & 2.5498 & 0.9000 & 14.1 & 0.0118 & 2.7101 & 0.9600 & 10 \\
\hline 2001-2002 & Trabzon & & & & & & & & & 10.9 & 0.0320 & 2.5078 & 0.8954 & 11 \\
\hline 2001-2002 & Sinop & & & & & & & & & 10.4 & 0.0241 & 2.6738 & 0.9134 & 11 \\
\hline 2001-2002 & Istanbul & & & & & & & & & 10.9 & 0.0111 & 2.9796 & 0.8649 & 11 \\
\hline 2004-2005 & Sinop-Samsun & & & & & & & & & 15.2 & 0.0066 & 2.9669 & 0.9600 & 12 \\
\hline 2004-2005 & Rize & & 0.0067 & 2.9709 & & & 0.0089 & 2.8445 & & 15.0 & 0.0101 & 2.7948 & 0.9286 & 13 \\
\hline $2005-2006$ & Rize & & 0.0042 & 3.1518 & & & 0.0045 & 3.1187 & & 15.0 & 0.0055 & 3.0425 & & 13 \\
\hline 2010-2011 & Sinop-Trabzon & & 0.0170 & 2.5760 & 0.9240 & & 0.0180 & 2.5470 & 0.8510 & 14.8 & 0.0110 & 2.7420 & 0.9350 & 14 \\
\hline 2013-2014 & Trabzon-Rize & 13.2 & 0.0078 & 2.8757 & 0.8800 & 13.8 & 0.0159 & 2.5609 & 0.8100 & 13.8 & 0.0120 & 2.6880 & 0.8500 & 15 \\
\hline
\end{tabular}

1: Erkoyuncu \& Özdamar (1989); 2: Karacam \& Düzgünes (1990); 3: Ünsal (1989); 4: Mutlu (1994); 5: Özdamar et al., (1995); 6: Kayalı (1998); 7: Mutlu (2000); 8: Gözler \& Çiloğlu (1998); 9: Samsun et al., (2004); 10: Samsun et al., (2006); 11: Aka et al., (2004); 12: Bilgin et al., (2006); 13: Şahin et al., (2008); 14: Erdoğan Sağlam \& Sağlam (2010); 15: Present study. 
The reported $b$ values for combined specimens ranged between 2.5078 and 3.4157 (mean: $2.9439 \pm 0.05021, \mathrm{n}=20$ ) (Table 1). From the reported $b$ values for different fishing seasons from the Black Sea, it can be inferred that this fish species exhibits different growth characteristics by different time intervals. Our data fit the regression for the species E. encrasicolus excellently and growth parameters are similar to five of the eight results of fishing seasons conducted after the 2000s in the Black Sea (Fig. 3). Similarly, when the $b$ values were evaluated according to sexes, our $b$ values (2.8757 in males and 2.5609 in females) are similar to the studies (Samsun et al., 2004; Samsun et al., 2006); Şahin et al., 2008; Erdoğan Sağlam \& Sağlam, 2010) conducted after the 2000 s in the Black Sea. Namely, the $b$ values of the WLRs showed that sampled specimens has negative allometric growth characteristics $(b<3)$ both females and males $(P<$ 0.05) after the 2000s in the Black Sea. Based on the slope (b) of the relation between $W$ and $L$, it can be checked whether the growth of a fish species is isometric $(b=3)$, hypoallometric $(b<3)$ and hyperallometric $(b>3)$ (Le Cren, 1951; Frose, 2006; Froese et al., 2011). In such a way that if the $b=3$, all fish dimensions increase at the same rate, if the $b<3$, a fish increases less in weight than predicted by its increase in length, i.e., it becomes more elongated, if the $b>3$, a fish increases more in weight than predicted by its increase in length, i.e., it becomes less elongated or more roundish (Le Cren (1951; Froese et al., 2011).

Historical evaluation of the $b$ values (Fig. 3) has shown that anchovy have become more elongated in recent years $(b<3)$. The differences in the $b$ values may be due to seasonal changes in the water temperature and the maturity stage, different sampling area, age, sex and differences of other biotic and abiotic factors such as salinity, competition, food and feeding, degree of stomach fullness, etc. Furthermore, the overfishing on anchovy stocks has shown itself in fish growth over the years (from 1985 to present time). This time period can be divided into three parts according to the exploitation ratio $(E)$ levels and the slope values of the WLRs for Anchovy. First time period; 1985s years when fishing pressure has just started $(b>3)$. Second period; the years when the fishing pressure continues to increase $(b=3)$ and third time period; recent years when stocks are completely affected due to overfishing $(b<3)$. Namely, the anchovy individuals are more roundish-plump $(b>3)$ in the 1985 s that time fishing pressure has just begun on stocks and exploitation rate about 0.5 (Karacam \& Düzgünes, 1990), all fish dimensions increase at the same rate $(b=3)$ with the effect of overfishing (exploitation rate, $E>0.5$ ) had continued for many years (Bilgin, 2006), and it becomes more elongated in recent years $(b<3)$ when stocks are completely affected due to overfishing (Bilgin et al., 2016). The correlation coefficient $(r)$ both females and males has higher correlation in the WLRs equations and also $\log (a)$ values were plotted against $b$ values for E. encrasicolus proved to be consistent with previous studies data (Fig. 2). Similar result for different fish species such as thornback ray (Raja clavata), turbot (Scophthalmus maximus) and scaldback (Arnoglossus kessleri) was reported by Bilgin \& Köse (2018) and Bilgin \& Onay (2019) from the Black Sea.

In conclusion, it has been historically determined that the Anchovy exhibited positive allometric growth in the mid-1985, isometric growth for next 15 years and negative allometric growth after the 2000s. Namely, historical evaluation of the $b$ values has shown that anchovy have become more elongated in recent years. The obtained results on the WLRs parameters by fishing seasons are expected to be helpful in support of sustainable fisheries management of this key fish species in the Black Sea, Turkey.

\section{ACKNOWLEDGMENTS}

This study is summarized from the master's thesis and supported by Recep Tayyip Erdoğan University, Faculty of Fisheries and Aquaculture.

\section{REFERENCES}

Aka, Z., Torcu Koç, H. \& Turan, C. (2004). A study on the growth of the anchovy Engraulis encrasicolus, Linnaeus (1758) in Turkish Seas. Pakistan Journal of Biological Sciences, 7(7), 1121-1126.

Bilgin, S. (2006). Evaluated of anchovy, Engraulis encrasicolus (L., 1758), fishing (1985-2005 fishing seasons) Turkish coast (Black Sea) in respect to fisheries biology. Erciyes University, Journal of Science and Technology, 22(1-2), 213222.

Bilgin, S., Samsun, N., Samsun, O. \& Kalaycı, F. (2006). Estimation of population parameters of anchovy, Engraulis encrasicolus L. 1758, at 2004-2005 fishing season in the Middle Black Sea, using length frequency analysis methods. Ege Journal of Fisheries and Aquatic Sciences, 23(1/3), 359364.

Bilgin, S., Taşçı, B. \& Bal, H. (2013). Sexual seasonal growth of the European anchovy (Engraulis encrasicolus) caught by mid-water trawl and purse seine in the southern Black Sea. Journal of the Marine Biological Association of the United Kingdom, 93(2), 333-339. DOI 10.1017/S0025315412000732

Bilgin, S., Sümer, Ç., Bektaş, S., Satılmış, H.H. \& Bircan, R. (2016). Evaluation of anchovy (Engraulis encrasicolus) population dynamics studies (1985-2015) in terms of fisheries 
management in the Black Sea. Ege Journal of Fisheries and Aquatic Sciences, 33(2), 169-182. DOI: 10.12714/egejfas.2016.33.2.12

Bilgin, S. \& Köse, O. (2018). Length-weight relationships (LWRs) of target fish turbot, Scophthalmus maximus (Pleuronectiformes: Scophthalmidae) and non-target fish thornback ray, Raja clavata (Rajiformes: Rajidae) caught by turbot gill net fishery in the Black Sea, Turkey. Cahiers de Biologie Marine, 59, 615-622. Doi: 10.21411/CBM.A.546928E7.

Bilgin, S. \& Onay, H. (2019). Weight-length relationships (WLRs) of scaldback, Arnoglossus kessleri Schmidt, 1915 (Pleuronectiformes: Bothidae), caught by beam trawl in the Southeastern Black Sea (Rize, Turkey). Anatolian Env. and Anim. Sciences, 4(3), 354-358. DOI: 10.35229/jaes.596048.

Erdoğan Sağlam, N. \& Sağlam, C. (2013). Age, growth and mortality of anchovy Engraulis encrasicolus in the south-eastern region of the Black Sea during the 2010-2011 fishing season. Journal of the Marine Biological Association of the United Kingdom, 93, 2247-2255. DOI: $10.1017 / \mathrm{S} 0025315413000611$

Erkoyuncu, I. \& Ozdamar, E. (1989). Estimation of the age, size and sex composition and growth parameters of anchovy, Engraulis encrasicolus (L.) in the Black Sea. Fisheries Research, 7, 241247.

Froese, R. (2006). Cube law, condition factor and weightlength relationships: history, meta-analysis and recommendations. Journal of Applied Ichthyology, 22, 241-253. DOI: 10.1111/j.14390426.2006.00805.x.

Froese, R., Tsikliras, A.C. \& Stergiou, K.I. (2011). Editorial note on weight-length relations of fishes. Acta Ichthyologica et Piscatoria, 41, 261-263. DOI: 10.3750/AIP2011.41.4.01.

Froese, R. \& Pauly, D. (2019). FishBase. World Wide Web electronic publication. www.fishbase.org, version (12/2019).

Gözler, A.M. \& Çiloğlu, E. (1998). A study on some population parameters of anchovy (Engraulis encrasicolus L., 1758) caught 1997-1998 fishing season off Rize-Hopa. Eastern Anatolia Region III. Symposium on Fisheries 1998 (pp. 373-382). Erzurum, Turkey. Proceedings Book.

Hammer, Ø., Harper, D.A.T. \& Ryan, P.D. (2001). PAST: Paleontological statistics software package for education and data analysis. Palaeontologia Electronica, 4, 1-9.

Karacam, H. \& Düzgünes, E. (1990). Age, growth and meat yield of the European anchovy (Engraulis encrasicolus, L. 1758) in the Black Sea. Fisheries Research, 9, 181-186.

Kayalı, E. (1998). A study on the biological characteristics of anchovy (Engraulis encrasicolus, L., 1758) and horse mackerel (Trachurus mediterranues) in the Eastern Black Sea ecosystem. M.Sc Thesis, Black Sea Technical University, Institute of Science and
Technology, Department of Fisheries Technology Engineering. Trabzon, Turkey, 238p.

Le Cren, E.D. (1951). The length-weight relationship and seasonal cycle in gonad weight and condition in the perch (Perca fluviatilis). Journal of Animal Ecology, 20(2), 201-219.

Lisovenko, L.A. \& Andrianov, D.P. (1996). Reproductive biology of anchovy (Engraulis encrasicolus ponticus Alexandrov 1927) in the Black Sea. Scientia Marina, 60 (Supl. 2), 209218.

Mazlum, R.E., Solak, E. \& Bilgin, S. (2017). Size and seasonal diet variation of European anchovy, Engraulis encrasicolus (Linnaeus, 1758) in the southeast Black Sea. Cahiers de Biologie Marine, 58(3), 251-260. DOI: 10.21411/CBM.A.B2C2DBE2

Mutlu, C. (1994). A study on the some population characteristics of anchovy (Engraulis encrasicolus, L., 1758) in the Eastern Black Sea. M.Sc Thesis, Black Sea Technical University, Institute of Science and Technology, Department of Fisheries Technology Engineering. Trabzon, Turkey, 44p.

Mutlu, C. (2000). Population characteristics and implementation of analytical methods for the prediction of the stock quantity of anchovy (Engraulis encrasicolus Linnaeus, 1758) in the Eastern Black Sea. PhD Thesis, Black Sea Technical University, Institute of Science and Technology, Department of Fisheries Technology Engineering. Trabzon, Turkey, 112p.

Oliveira, M.R., Costa E.F.S., Araújo, A.S., Pessoa, E.K.R., Carvalho, M.M., Cavalcante, L.F.M. \& Chellappa, S. (2012). Sex ratio and length-weight relationship for five marine fish species from Brazil. Journal of Marine Biology \& Oceanography, 1(2), 1-3. DOI: 10.4172/23248661.1000103.

Özdamar, E., Samsun, O. \& Erkoyuncu, I. (1995). The estimation of population parameters for anchovy (Engraulis encrasicolus, L.) during 1994-1995 fishing season in the Turkish Black Sea region. Ege University Faculty of Fisheries, Journal of Fisheries and Aquatic Sciences, 12(1-2), 135-144.

Pauly, D. (1984). Fish population dynamics in tropical water: a manual for use with programmable calculators. The International Center for Living Aquatic Resources Management, Makati, Metro Manila, Philippines, 323p.

Ribeiro, R., Reis, J., Santos, C., Gonçalvesa, F. \&. Soares A.M.V.M. (1996). Spawning of anchovy Engraulis encrasicolus in the Mondego Estuary, Portugal. Estuarine, Coastal and Shelf Science, 42, 467-482. DOI: 10.1006/ecss.1996.0030

Şahin, C., Akın, Ş., Hacımurtazaoğlu, N., Mutlu, C. \& Verep, B. (2008). The stock parameter of anchovy (Engraulis encrasicolus) population on the coasts of the eastern Black Sea: reason and implications in declining of anchovy population during the 2004-2005 and 2005-2006 fishing 
seasons. Fresenius Environmental Bulletin, 17(12b), 2159-2169.

Samsun, O., Samsun, N. \& Karamollaoğlu, A.C. (2004). Age, growth and mortality rates of the European anchovy (Engraulis encrasicolus L. 1758) in the Turkish Black Sea Coast. Turkish Journal of Veterinary and Animal Sciences, 28(5), 901-910.

Samsun, O., Samsun, N., Kalaycı, F. \& Bilgin, S. (2006). A study on recent variations in the population structure of European Anchovy (Engraulis encrasicolus L., 1758) in the southern Black Sea. E.U. Journal of Fisheries and Aquatic Sciences, 23(3-4), 301-306.

Snedecor, G.W. \& Cochran, W.G. (1989). Statistical methods, Iowa State University Press, Ames, Iowa, USA, 803p.

Stergiou, K. I. \& Moutopoulos, D.K. (2001). A review of length-weight relationships of fishes from Greek marine waters. Naga, the ICLARM Quarterly, 24, 23-39.

Ünsal, N. (1989). A study on age-length-weight relationship and determination of the smallest catching size of anchovy, Engraulis encrasicolus (L.) in the Black Sea. Istanbul University Journal of Aquatic Products, 3(1-2), 17-28. 